\title{
Oncologist
}

\section{Antitumor Effects of Somatostatin Analogs in Neuroendocrine Tumors}

\author{
Lucas Sidéris, ${ }^{a}$ Pierre Dubé, a Anja Rinke ${ }^{b}$ \\ ${ }^{\mathrm{a} D e p a r t m e n t ~ o f ~ S u r g e r y, ~ U n i v e r s i t y ~ o f ~ M o n t r e a l, ~ M o n t r e ́ a l, ~ Q u e b e c, ~ C a n a d a ; ~}{ }^{\mathrm{b}}$ Department of \\ Gastroenterology and Endocrinology, University of Marburg, Marburg, Germany
}

Key Words. Octreotide $•$ Lanreotide $•$ Pancreatic neuroendocrine tumors $•$ Gastrointestinal neuroendocrine tumors $•$ Carcinoid

Disclosures: Lucas Sidéris: Novartis, Pfizer (C/A, H); Novartis (RF); Pierre Dubé: Roche, Novartis, Sanofi (C/A); Anja Rinke: Ipsen (C/A); Novartis, Ipsen, Pfizer $(\mathrm{H})$

(C/A) Consulting/advisory relationship; (RF) Research funding; (E) Employment; (H) Honoraria received; (OI) Ownership interests; (IP) Intellectual property rights/inventor/patent holder; (SAB) Scientific advisory board

\begin{abstract}
Background. For decades, somatostatin analogs (including octreotide and lanreotide) have been indicated for relief of the symptoms of flushing, diarrhea, and wheezing associated with secretory neuroendocrine tumors (NETs). Recently, it has been suggested that somatostatin analogs may provide direct and indirect antitumor effects in secretory and nonsecretory NETs in addition to symptom control in secretory NETs.

Methods. A systematic review of MEDLINE was conducted to identify studies that investigated the antitumor effects of octreotide or lanreotide for patients with NETs. Additional studies not published in the peer-reviewed literature were identified by searching online abstracts.

Results. In all, 17 octreotide trials and 11 lanreotide trials that included antitumor effects were identified. Partial response rates were between $0 \%$ and $31 \%$, and stable disease
\end{abstract}

rates were between $15 \%$ and $89 \%$. Octreotide was the only somatostatin analog for which results of a phase III, randomized, placebo-controlled clinical trial that investigated antitumor effects were published. After 6 months of treatment in this randomized phase III trial, stable disease was observed in $67 \%$ of patients (hazard ratio for time to disease progression: $0.34 ; 95 \%$ confidence interval: $0.20-$ $0.59 ; p=.000072$ ).

Conclusions. In addition to symptom control for NETs, the data support an antitumor effect of somatostatin analogs and suggest that they may slow tumor growth. Longacting repeatable octreotide has been shown to have an antitumor effect in a randomized phase III trial in midgut NETs, whereas results are pending in a corresponding controlled trial with lanreotide for patients with intestinal and pancreatic primary NETs. The Oncologist 2012;17:747-755

\section{INTRODUCTION}

Advanced neuroendocrine tumors (NETs) are a family of malignancies with diverse origins, including the gastrointestinal (GI) tract, lung, and pancreas [1-3]. Primary treatment guidelines for NETs include surgical resection of the tumor, if possible $[1,4]$. The 5 -year survival rate is $51 \%-80 \%$, depending on the disease location and stage [4]. However, tumors may recur after surgery; for example, liver metastases have an $84 \%-91 \%$ probability of recurrence at 5 years [4]. In addition, up to $50 \%$ of patients with NETs have metastases at diagnosis [3], and the presence of metastasis portends a significantly worse prognosis [4].

Despite common histopathologic characteristics, GI-NETs (previously known as carcinoid tumors) and pancreatic NETs (pNETs) should be differentiated on the basis of biological behavior and therapeutic strategy. Although NETs have the potential to secrete specific hormones or vasoactive peptides into the systemic circulation, thus resulting in a broad range of 


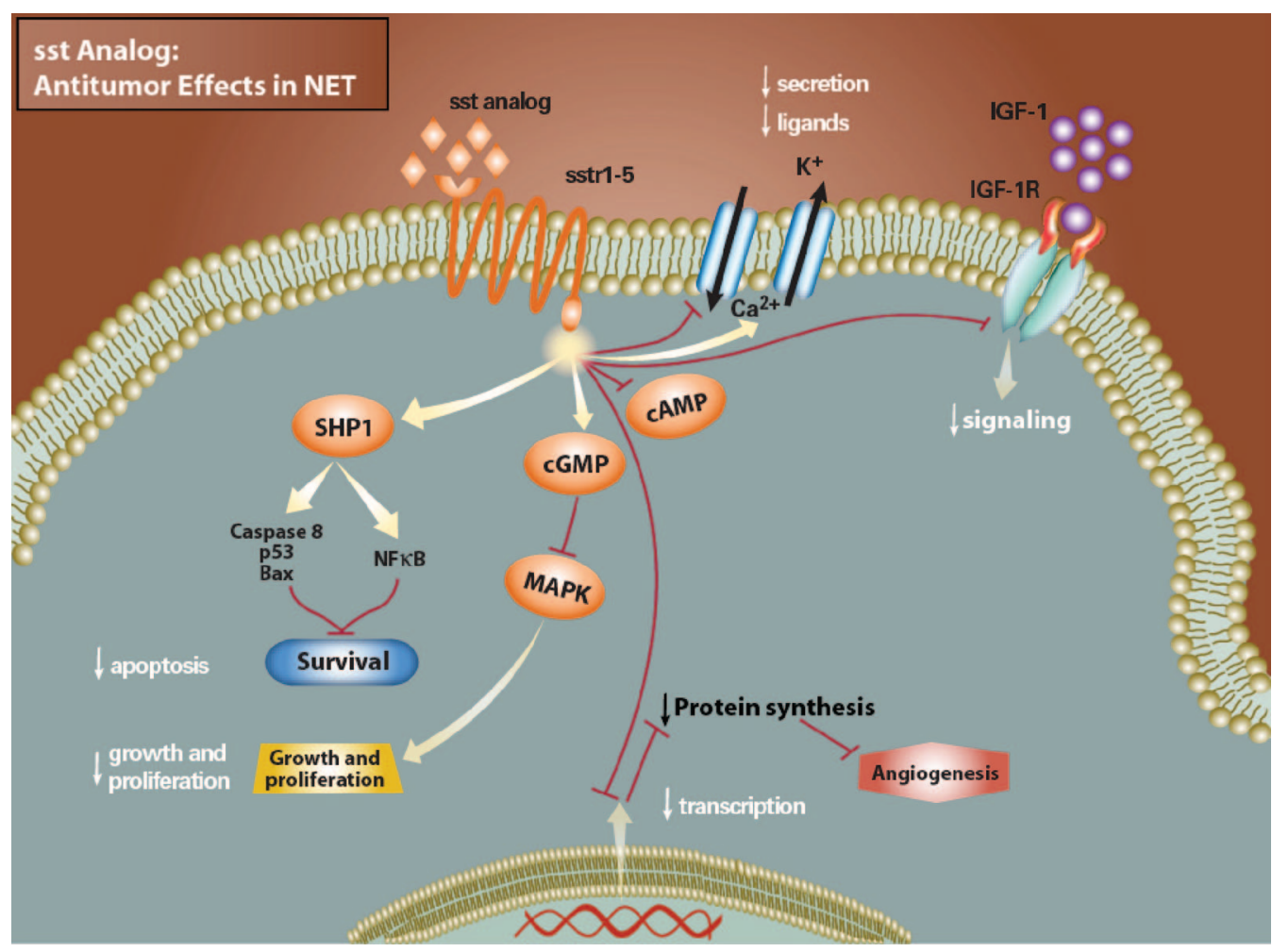

Figure 1. Effect of somatostatin analog in neuroendocrine tumors. Somatostatin analogs bind to G-protein-linked receptors on the cell surface and cause decreased hormonal secretion by inhibiting cyclic adenosine monophosphate, increased apoptosis by activating the protein tyrosine phosphatase SHP1, decreased growth and proliferation through mitogen-activated protein kinase, inhibition of insulinlike growth factor receptor 1 signaling, and inhibition of protein synthesis caused by decreased transcription [12].

Abbreviations: cAMP, cyclic adenosine monophosphate; cGMP, cyclic guanosine monophosphate; IGF, insulin-like growth factor; IGF-1R, insulin-like growth factor receptor 1; MAPK, mitogen-activated protein kinase; NET, neuroendocrine tumor; NF $\kappa \mathrm{B}$, nuclear factor- $\kappa$ B; SHP1, Src homology phosphatase-1; sst, somatostatin.

symptoms [2], most patients $(60 \%)$ have nonfunctioning tumors. Although most pNETs are nonsecreting, many GI-NETs are associated with symptoms of flushing, diarrhea, and wheezing [2]; the constellation of these symptoms is called carcinoid syndrome. Secreting pNETs occur, in decreasing frequency, as insulinomas (causing hypoglycemia), gastrinomas (causing Zollinger-Ellison syndrome), glucagonomas (causing weight loss, diabetes, and/or skin lesions), VIPomas (i.e., Verner-Morrison syndrome; causing profuse diarrhea, hypokalemia, and flushing), and others (e.g., somatostatinomas) $[2,5]$.

Most NETs express G-protein-coupled transmembrane somatostatin receptors (SSTRs) [6]. There are five subtypes of SSTRs, and different NETs have differing proportions of SSTR expression [6]. Somatostatin inhibits the release of neuroendocrine hormones, including those released from NETs. However, somatostatin has a short half-life in vivo [6], making it unsuitable for therapeutic use; thus, synthetic somatostatin analogs were developed for NET symptom control [7-11]. A subcutaneous (SC) formulation of octreotide was approved in New Zealand (1987), followed by octreotide long-acting repeatable (LAR) some years later; both are approved in more than 90 countries worldwide for the control of hormonal symptoms in patients with GI-NETs and pNETs [10]. Lanreotide SC first became available in 1988 in Europe; lanreotide longacting microparticle formulation (LA) was approved for relief of NET symptoms in 1995 in France, and lanreotide Autogel was approved in 2001 in the European Union [9].

Like somatostatin, octreotide and lanreotide bind to the SSTR and produce a range of effects, including decreased hormonal secretion, decreased growth and proliferation, increased apoptosis, inhibition of cell signaling, and inhibition of protein synthesis; they may also have direct antiproliferative activity (Fig. 1) [12, 13]. There are 25 years of evidence that octreotide controls the symptoms of severe diarrhea and flushing in patients with carcinoid syndrome [14-16]. Analysis of the Surveillance, Epidemiology, and End Results (SEER) database found that patients with metastatic NETs who were diagnosed between 1988 and 2004 had significantly greater median survival times than patients with metastatic NETs who were diagnosed between 1973 and 1987 (39 vs. 18 months, respectively; hazard ratio [HR]: $0.73 ; 95 \%$ confidence interval [CI]: $0.69-0.77 ; p<.001$ ) [3]. Notably, this improvement coincides with the introduction of octreotide in 1987. Before the introduction of somatostatin analogs, many patients may have died from the effects of associated secretion syndromes (e.g., long-term diarrhea, ultimately resulting in severe dehydration 
and renal failure [17]); today, the highest mortality rate is for patients with high tumor burdens.

In addition to symptom control, it has long been suggested that somatostatin analogs may exert antitumor effects for NETs. Even before its approval, case reports suggested that octreotide showed antitumor properties for patients with NETs $[18,19]$. Reviews of preclinical studies suggest direct receptor-mediated antitumor effects of cell cycle inhibition, growth factor inhibition, and proapoptotic activity [20, 21]. Furthermore, there may be indirect effects, including inhibition of the release of growth factor and trophic hormones, inhibition of angiogenesis, and modulation of the immune system [20, 21]. Based on these data, we reviewed the literature to identify published primary clinical studies and retrospective analyses that supported an antitumor role for the somatostatin analogs octreotide and lanreotide.

\section{MeTHODS}

Systematic review of the literature was conducted to identify primary prospective and retrospective studies examining the antitumor effects of octreotide or lanreotide in patients with NETs. Additional studies not published in the peer-reviewed literature were identified by searching online abstracts from the American Society of Clinical Oncology (ASCO), ASCO Gastrointestinal Cancers Symposium (ASCO-GI), European Society for Medical Oncology (ESMO), and the North American Neuroendocrine Tumor Society (NANETS) annual congresses.

\section{Peer-Reviewed Literature}

PubMed was searched using the search terms of "endocrine tumor" or "endocrine tumour" or "carcinoid" or "gastroenteropancreatic" (defined as the disease search). The search was limited to English language studies of humans. Results of the disease search were further limited to articles containing the terms "octreotide" or "Sandostatin" or "lanreotide" or "Somatuline Autogel" or "somatostatin analog" in the title or abstract (defined as the drug search). Results of the drug search were critically evaluated to select primary clinical trials or retrospective analyses of octreotide or lanreotide on tumor progression (defined as studies reporting tumor response rates and/or survival rates). In the first instance, titles and abstracts from the drug search were examined to assess whether publications fit the defined criteria for inclusion in our analysis; if insufficient information was available, then the complete published article was obtained and examined.

Review articles and case studies were excluded, as were articles pertaining to symptom control of NETs, radiolabeled octreotide, preclinical studies, octreotide in imaging/diagnosis, and acromegaly. To capture as many relevant articles as possible, citations of selected articles and other recent reviews on octreotide or lanreotide for NETs (published in the past 5 years) were also examined. For each article included in our analysis, the complete publication was obtained and evaluated.

\section{Congress Abstracts}

ASCO, ASCO-GI, ESMO, and NANETS online abstracts were searched for those containing "octreotide" or "Sandosta- tin" or "lanreotide" or "Somatuline Autogel." The search results were evaluated to select primary clinical trials or retrospective analyses of octreotide or lanreotide on tumor progression. The first author was then searched through PubMed to determine whether the studies had since been published in the peer-reviewed literature.

\section{RESULTS}

The disease search yielded 9,590 articles published in the English language that contained the search terms "endocrine tumor" or "endocrine tumour" or "carcinoid" or "gastroenteropancreatic" in humans.

\section{Octreotide}

Further limitation to the drug search using the terms "octreotide" or "Sandostatin" or "somatostatin analog" in the title or abstract narrowed the results down to 671 articles. Evaluation of those 671 articles identified 12 primary clinical trials for inclusion in this review [22-33]. Another three articles for inclusion were selected based on the citations of these studies and/or recent reviews [34-36]. Review of ASCO, ASCO-GI, ESMO, and NANETS abstracts online identified one additional study for inclusion [37]. No retrospective analyses were identified, and one placebocontrolled trial was identified. The final search results for octreotide are shown in Table 1.

Shortly after octreotide approval in 1987, Vinik and Moattari [33] reported results from an uncontrolled openlabel trial of octreotide SC and demonstrated partial response and stable disease in $20 \%$ and $50 \%$ of patients, respectively. Six studies in the following decade showed that $15 \%-86 \%$ of patients with advanced NETs achieved stable disease with octreotide SC (Table 1) [22, 23, 26, 28, $29,31]$. After the introduction of octreotide LAR, several more studies reinforced the results observed with the SC formulation [27, 30, 32, 34-37]. Overall, stable disease was observed in $15 \%-88 \%$ of patients with advanced, functioning, or nonfunctioning NETs (Table 1). The studies described in Table 1 revealed that stable disease was observed in up to $86 \%$ of patients who received octreotide SC, up to $88 \%$ of patients who received octreotide LAR, and approximately $50 \%$ of patients with progressive disease before treatment. Partial response (when reported) was observed in up to $31 \%$ of patients receiving octreotide SC and up to $11 \%$ of patients who received octreotide LAR; however, in most newer trials using a standardized partial response definition such as Response Evaluation Criteria in Solid Tumors (RECIST), the partial response rate did not exceed $10 \%$ (Table 1) [38].

Evidence of an antitumor effect of octreotide in patients with NETs was confirmed with the results of the PlaceboControlled, Double-Blind, Prospective, Randomized Study of the Effect of Octreotide LAR in the Control of Tumor Growth in Patients with Metastatic Neuroendocrine Midgut Tumors (PROMID) [38]. PROMID was a phase IIIb, prospective, randomized, placebo-controlled, double-blind study of 85 evaluable patients with well-differentiated ad- 
Table 1. Prospective clinical trials of octreotide for neuroendocrine tumors

\begin{tabular}{|c|c|c|c|c|c|c|c|}
\hline \multirow[b]{2}{*}{ Study } & \multirow{2}{*}{$\begin{array}{l}n \text { of patients } \\
\text { monitored for } \\
\text { tumor } \\
\text { response }\end{array}$} & \multirow[b]{2}{*}{ Inclusion criteria } & \multirow[b]{2}{*}{ Patient characteristics } & \multirow[b]{2}{*}{ Treatment } & \multirow[b]{2}{*}{$\begin{array}{l}\text { Duration of drug } \\
\text { administration }\end{array}$} & \multicolumn{2}{|c|}{$\begin{array}{l}\% \text { of patients with } \\
\text { tumor response }\end{array}$} \\
\hline & & & & & & $\begin{array}{l}\text { Partial } \\
\text { response }\end{array}$ & $\begin{array}{l}\text { Stable } \\
\text { disease }\end{array}$ \\
\hline $\begin{array}{l}\text { Vinik and } \\
\text { Moattari } \\
\text { (1989) [33] }\end{array}$ & 10 & $\begin{array}{l}\text { Metastatic carcinoid or } \\
\text { pNET }\end{array}$ & $\begin{array}{l}\text { Previous surgical resection in } \\
100 \% \text {; previous chemotherapy in } \\
30 \%\end{array}$ & $\begin{array}{l}\text { Octreotide s.c. } 100-250 \\
\mu \mathrm{g} \text { every } 6-12 \text { hours }\end{array}$ & $6-24 \operatorname{mos}$ & 20 & 50 \\
\hline $\begin{array}{l}\text { Oberg et al. } \\
\text { (1991) [29] }\end{array}$ & 22 & $\begin{array}{l}\text { Metastatic midgut } \\
\text { carcinoids }\end{array}$ & $\begin{array}{l}\text { Previous surgical resection in } \\
52 \% \text {; previous interferon therapy } \\
\text { in } 57 \% \text {; previous chemotherapy in } \\
30 \%\end{array}$ & $\begin{array}{l}\text { Octreotide s.c. } 50 \mu \mathrm{g} \\
\text { b.i.d. up to median of } \\
200 \mu \mathrm{g} 3-4 \text { times/day }\end{array}$ & $\begin{array}{l}1-30 \text { mos; median } \\
12 \text { mos }\end{array}$ & 28 & 36 \\
\hline $\begin{array}{l}\text { Anthony et al. } \\
\text { (1993) [23] }\end{array}$ & 14 & Metastatic NET & $\begin{array}{l}10 \text { patients had PS of } 80 \%-100 \% \text {; } \\
4 \text { patients had PS of } 60 \%-79 \%\end{array}$ & $\begin{array}{l}\text { Octreotide s.c. } 500- \\
2000 \mu \text { g every } 8 \text { hours }\end{array}$ & NS & 31 & 15 \\
\hline $\begin{array}{l}\text { Saltz et al. } \\
\text { (1993) [31] }\end{array}$ & 34 & $\begin{array}{l}\text { Progressive, advanced } \\
\text { carcinoid or pNET }\end{array}$ & Previous chemotherapy in $38 \%$ & $\begin{array}{l}\text { Octreotide s.c. } 50 \mu \mathrm{g} \\
\text { b.i.d. to } 150-250 \mu \mathrm{g} \\
\text { t.i.d. }\end{array}$ & $\begin{array}{l}1-47 \text { mos; median } \\
29 \text { mos }\end{array}$ & 0 & 50 \\
\hline $\begin{array}{l}\text { Arnold et al. } \\
\text { (1996) [26] }\end{array}$ & 103 & $\begin{array}{l}\text { Moderate or well- } \\
\text { differentiated } \\
\text { advanced carcinoid or } \\
\text { pNET }\end{array}$ & $\begin{array}{l}5 \% \text { had KPS }<50,41 \% \text { had KPS } \\
50-70,51 \% \text { had KPS } 80-100 \\
\text { Previous interferon therapy in } 9 \% \text {; } \\
\text { previous chemotherapy in } 20 \%\end{array}$ & $\begin{array}{l}\text { Octreotide s.c. } 200-500 \\
\mu \text { g t.i.d. }\end{array}$ & $\begin{array}{l}>6 \text { mos; follow- } \\
\text { up to } 36 \text { mos in } \\
\text { some patients }\end{array}$ & 0 & 48 \\
\hline $\begin{array}{l}\text { di Bartolomeo } \\
\text { et al. (1996) } \\
\text { [28] }\end{array}$ & 58 & $\begin{array}{l}\text { Progressive, advanced } \\
\text { carcinoid or pNET }\end{array}$ & $\begin{array}{l}\text { ECOG PS } 0-1 \text { in } 93 \% \text {; ECOG PS } \\
2 \text { in } 7 \% \\
\text { Previous surgical resection in } \\
60 \% \text {; previous chemotherapy in } \\
16 \%\end{array}$ & $\begin{array}{l}\text { Octreotide s.c. } 500 \\
(n=23) \text { or } 1,000 \\
(n=35) \text { t.i.d. }\end{array}$ & $\begin{array}{l}2-32+\operatorname{mos} \\
\text { median } 5 \text { mos }\end{array}$ & 3 & 47 \\
\hline $\begin{array}{l}\text { Angeletti et al. } \\
\text { (1999) [ 22] }\end{array}$ & 9 & $\begin{array}{l}\text { Metastatic GEP-NET } \\
\text { or pNET }\end{array}$ & $\begin{array}{l}\text { Previous surgical resection in } \\
100 \%\end{array}$ & $\begin{array}{l}\text { Octreotide s.c. } 500 \mu \mathrm{g} \\
\text { every day }\end{array}$ & $12 \mathrm{mos}$ & 11 & 67 \\
\hline $\begin{array}{l}\text { Ricci et al. } \\
(2000)[30]\end{array}$ & 15 & $\begin{array}{l}\text { Progressive, advanced } \\
\text { carcinoid or pNET }\end{array}$ & $\begin{array}{l}\text { ECOG PS } 0 \text { in } 27 \% \text {, ECOG PS } 1 \\
\text { in } 73 \% \\
\text { Previous surgical resection in } \\
100 \% \text {, previous chemotherapy in } \\
7 \%\end{array}$ & $\begin{array}{l}\text { Octreotide LAR } 20 \mathrm{mg} \\
\text { every } 4 \text { wks }\end{array}$ & $\begin{array}{l}3-12+\text { mos; } \\
\text { median } 7 \text { mo }\end{array}$ & 7 & 40 \\
\hline $\begin{array}{l}\text { Tomassetti et al. } \\
(2000)[32]\end{array}$ & 16 & $\begin{array}{l}\text { Advanced carcinoid or } \\
\text { pNET }\end{array}$ & Previous surgical resection in $69 \%$ & $\begin{array}{l}\text { Octreotide LAR } 20 \mathrm{mg} \\
\text { every } 28 \text { days }\end{array}$ & $\begin{array}{l}6-15 \text { mos; mean } \\
11 \text { mos }\end{array}$ & 0 & 88 \\
\hline $\begin{array}{l}\text { Aparicio et al. } \\
\text { (2001) [24] }\end{array}$ & 17 & $\begin{array}{l}\text { Progressive, advanced } \\
\text { carcinoid or pNET }\end{array}$ & $\begin{array}{l}\text { PS } 0 \text { in } 54 \% \text {; PS } 1 \text { in } 40 \% \text {; PS }>1 \\
\text { in } 6 \% \\
\text { Previous surgical resection in } \\
77 \% \text {; previous chemotherapy in } \\
74 \%\end{array}$ & $\begin{array}{l}\text { Octreotide s.c. } 100 \mu \mathrm{g} \\
\text { t.i.d. }\end{array}$ & $\begin{array}{l}1-48 \text { mos; median } \\
7 \operatorname{mos}^{\mathrm{a}}\end{array}$ & NS & 59 \\
\hline $\begin{array}{l}\text { Shojamanesh } \\
\text { et al. (2002) } \\
\text { [36] }\end{array}$ & 13 & Gastrinoma & Previous surgical resection in $73 \%$ & $\begin{array}{l}\text { Octreotide s.c. } 100-200 \\
\mu \mathrm{g} \text { every } 12 \text { hours or } \\
\text { octreotide LAR } 20-30 \\
\text { mg every mo }\end{array}$ & $3-54 \operatorname{mos}$ & 8 & 54 \\
\hline $\begin{array}{l}\text { Arnold et al. } \\
(2005)[25]\end{array}$ & 48 & $\begin{array}{l}\text { Progressive, advanced } \\
\text { carcinoid or pNET }\end{array}$ & $\begin{array}{l}\text { KPS }>70 \text { in } 100 \% \\
\text { Previous chemotherapy in } 8 \%\end{array}$ & $\begin{array}{l}\text { Octreotide s.c. } 200 \mu \mathrm{g} \\
\text { t.i.d. }\end{array}$ & $3 \mathrm{mos}$ & 2 & 46 \\
\hline $\begin{array}{l}\text { Bajetta et al. } \\
(2005)[27]\end{array}$ & 31 & $\begin{array}{l}\text { Advanced, well- } \\
\text { differentiated NET }\end{array}$ & $\begin{array}{l}\text { ECOG PS } 0 \text { in } 87 \% \text {, ECOG PS } 1 \\
\text { in } 13 \% \\
\text { Previous surgical resection in } 39 \%\end{array}$ & $\begin{array}{l}\text { Octreotide LAR } 30 \mathrm{mg} \\
\text { every } 28 \text { days }\end{array}$ & $\begin{array}{l}1-49 \text { mos; median } \\
18 \text { mos }\end{array}$ & 6 & 52 \\
\hline $\begin{array}{l}\text { Panzuto et al. } \\
\text { (2006) [35] }\end{array}$ & 21 & $\begin{array}{l}\text { Well-differentiated, } \\
\text { progressive, advanced } \\
\text { pNET }\end{array}$ & $\begin{array}{l}\text { Previous surgical resection in } \\
65 \% \text {; previous chemotherapy in } \\
13 \%\end{array}$ & $\begin{array}{l}\text { Octreotide LAR } 30 \mathrm{mg} \\
\text { every } 28 \text { days }\end{array}$ & $\begin{array}{l}6-60 \operatorname{mos} ; \text { median } \\
18 \operatorname{mos}^{\mathrm{a}}\end{array}$ & 0 & 48 \\
\hline $\begin{array}{l}\text { Butturini et al. } \\
\text { (2006) [34] }\end{array}$ & 21 & $\begin{array}{l}\text { Well-differentiated, } \\
\text { nonfunctioning } \\
\text { advanced pNET }\end{array}$ & Previous surgical resection in $19 \%$ & $\begin{array}{l}\text { Octreotide LAR } 20 \mathrm{mg} \\
\text { every } 28 \text { days }\end{array}$ & $\begin{array}{l}>74 \text { mos; median } \\
49.5 \text { mos }\end{array}$ & NS & 38 \\
\hline $\begin{array}{l}\text { Pavel et al. } \\
(2008)[37]\end{array}$ & 19 & $\begin{array}{l}\text { Nonfunctioning pNET } \\
\text { or bronchial tract NET }\end{array}$ & $\begin{array}{l}\text { KPS }>60 \% \text { in all patients } \\
\text { No previous therapies allowed }\end{array}$ & $\begin{array}{l}\text { Octreotide LAR } 30 \mathrm{mg} \\
\text { every mo }\end{array}$ & $6 \mathrm{mos}$ & 11 & 26 \\
\hline $\begin{array}{l}\text { Rinke et al. } \\
\text { (2011) [38] }\end{array}$ & 42 & $\begin{array}{l}\text { Well-differentiated } \\
\text { midgut NET }\end{array}$ & $\begin{array}{l}\text { KPS }>60 \% \text { in all patients; KPS } \\
>80 \% \text { in } 83 \% \\
\text { Previous surgical resection in } \\
69 \% \text {; no previous chemotherapy } \\
\text { allowed }\end{array}$ & $\begin{array}{l}\text { Octreotide LAR } 30 \text { mg } \\
\text { every mo }\end{array}$ & $6 \mathrm{mos}$ & 2 & 67 \\
\hline $\begin{array}{l}\text { Rinke et al. } \\
\text { (2011) [38] }\end{array}$ & 43 & $\begin{array}{l}\text { Well-differentiated } \\
\text { midgut NET }\end{array}$ & $\begin{array}{l}\text { KPS }>60 \% \text { in all patients; KPS } \\
>80 \% \text { in } 88 \% \\
\text { Previous surgical resection in } \\
63 \% \text {; no previous chemotherapy } \\
\text { allowed }\end{array}$ & Placebo & $6 \mathrm{mos}$ & 2 & 37 \\
\hline
\end{tabular}

${ }^{a}$ Median duration of treatment includes all drug regimens.

Abbreviations: ECOG, Eastern Cooperative Oncology Group; GEP, gastroenteropancreatic; KPS, Karnofsky performance status; LAR, long-acting repeatable; NET, neuroendocrine tumor; NS, not stated; pNET, pancreatic neuroendocrine tumor; PS, performance status. 
vanced midgut NETs [38]. Median time to tumor progression was 14.3 months (95\% CI: 11.0-28.8 months) with octreotide LAR and 6 months (95\% CI: 3.7-9.4 months) with placebo, with 26 and 40 instances of disease progression and tumor-related deaths, respectively (HR: 0.34; $95 \%$ CI: $0.20-0.59 ; p=.000072$ ) [38]. After 6 months of treatment, SD was observed in $67 \%$ of patients in the octreotide LAR group compared with $37 \%$ of patients in the placebo group [38]. Importantly, there was no difference in response between functionally active and inactive tumors; the most favorable effect was observed in patients with low hepatic tumor load and resected primary tumor [38]. Median overall survival time could not be estimated in the octreotide LAR group because of the crossover design of the study and was not considered statistically robust in the placebo group because of the low number of deaths.

Analyses to identify prognostic factors supporting an antitumor effect were conducted in several studies. A Karnofsky score $\geq 80[26]$ and hepatic tumor burden $\leq 10 \%$ indicated favorable prognosis [35, 38], whereas fast tumor growth rate in the 3-6 months before treatment $[24,36]$ and pancreatic primary tumor localization [35] indicated poor prognosis; all were significant in their respective studies. Interestingly, the ability to control symptoms or affect laboratory values was not an indicator of antitumor effect in any analysis. Prognostic factors with a trend toward response included tumor location, resection of primary tumor, time from diagnosis to drug initiation, tumor differentiation, and somatostatin analog scintigraphy response [24, 26-28, 35, 38].

Whether the observed benefit in progression-free survival coincides with the prolongation of overall survival is unclear. Median survival or overall survival rates were reported in several studies, but the variability in time periods (1-, 2-, and 3-year survival rates were variously reported) made them difficult to compare $[24,28,31,34,35,39]$. The HR for overall survival in an interim analysis of PROMID was 0.81 (95\% CI: $0.30-2.18 ; p=.77$ ) [38], with further evaluation of overall survival to be made. A trend toward better prognosis is consistent with analysis of the SEER database, which identified increased survival after the introduction of octreotide in 1987 [3].

\section{Lanreotide}

Limiting the disease search using the terms "lanreotide" or "Somatuline Autogel" or "somatostatin analog" in the title or abstract identified 174 potential articles. Critical evaluation of these articles yielded 10 final articles for inclusion [23, 24, 35, 40-46]. Review of ASCO, ASCO-GI, ESMO, and NANETS abstracts online identified one other study for inclusion [47]. No retrospective analyses or placebo-controlled results were identified. The final search results for lanreotide are shown in Table 2.

In comparison with octreotide, fewer studies could be found evaluating the potential antitumor effect of lanreotide, probably because of its shorter availability period and the more restricted geographic approval for NET treatment. Partial response and stable disease rates in published prospective stud- ies (most phase I or II) are similar to those reported for octreotide (Table 2). Data from the CLARINET trial (NCT00353496; a randomized, placebo-controlled, phase III trial of patients with nonfunctioning intestinal and pancreatic NETs) are not yet available, although enrollment was completed in June $2011(n=265)$.

Analyses to identify prognostic factors for antitumor response identified tumor location [35, 42, 43], tumor progression (fast vs. slow) [24], and distant extrahepatic metastases [35] as significant factors. Trends were also found between functional and nonfunctional tumors, tumor locations, and hepatic tumor burdens [35, 43, 44].

Survival benefits of patients responding to somatostatin ana$\log$ treatment compared with nonresponders were reported in two studies that investigated both octreotide and lanreotide [24, 35]. However, drug type was not investigated as a predictive factor.

\section{DISCUSSION}

The present analysis identified a number of studies supportive of the antitumor effects of the somatostatin analogs octreotide and lanreotide for patients with NETs. Although most of the octreotide studies were uncontrolled trials in heterogeneous populations, results were consistent with those from PROMID, which was the only randomized, placebo-controlled, phase III study [38]. PROMID demonstrated for the first time that octreotide LAR inhibits tumor progression in patients with welldifferentiated advanced midgut (or unknown location) NETs with or without secretory symptoms [38]. On the basis of these results, $30 \mathrm{mg}$ of octreotide LAR should be considered for patients with symptomatic and asymptomatic, well-differentiated, advanced midgut NETs.

In response to results from PROMID, several guidelines (including those by the National Comprehensive Cancer Network, the North American Neuroendocrine Tumor Society, and the European Society for Medical Oncology) have been updated to recommend $20-30 \mathrm{mg}$ of octreotide LAR as a management option for patients with recurrent or unresectable metastatic GI-NETs [1, 48-50]. Further studies including patients with pNETs and patients with primary tumor locations outside the midgut should be undertaken to clarify whether the antiproliferative effects of octreotide can be proven in these groups. Additional controlled trials in a larger number of patients are needed to identify prognostic factors to antitumor response and to confirm whether the antitumor effect of octreotide translates to a survival benefit.

No placebo-controlled studies have been published to date on the antitumor effect of lanreotide for patients with NETs. A double-blind, randomized, placebo-controlled, phase III study of lanreotide Autogel compared with placebo investigating progression-free survival in patients with nonsecretory enteropancreatic NETs (CLARINET) is ongoing. As noted here, results from uncontrolled prospective trials identified in the present literature search suggest that the rates of stable disease in patients treated with lanreotide (up to 89\%) are comparable with those observed in patients treated with octreotide in uncontrolled studies (up to $88 \%$ ).

There is also evidence to suggest that pasireotide 
Table 2. Prospective clinical trials of lanreotide in neuroendocrine tumors

\begin{tabular}{|c|c|c|c|c|c|c|c|}
\hline \multirow[b]{2}{*}{ Study } & \multirow{2}{*}{$\begin{array}{l}n \text { of patients } \\
\text { monitored for } \\
\text { tumor } \\
\text { response }\end{array}$} & \multirow[b]{2}{*}{ Inclusion criteria } & \multirow[b]{2}{*}{ Patient characteristics } & \multirow[b]{2}{*}{ Treatment } & \multirow[b]{2}{*}{$\begin{array}{l}\text { Duration of } \\
\text { drug } \\
\text { administration }\end{array}$} & \multicolumn{2}{|c|}{$\begin{array}{l}\% \text { of patients with } \\
\text { tumor response }\end{array}$} \\
\hline & & & & & & $\begin{array}{l}\text { Partial } \\
\text { response }\end{array}$ & $\begin{array}{l}\text { Stable } \\
\text { disease }\end{array}$ \\
\hline $\begin{array}{l}\text { Anthony et al. } \\
\text { (1993) [23] }\end{array}$ & 13 & Metastatic NET & $\begin{array}{l}5 \text { patients had PS of } \\
80 \%-100 \% ; 8 \text { patients had } \\
\text { PS } 60 \%-79 \%\end{array}$ & $\begin{array}{l}\text { Lanreotide } 750-3,000 \mu \mathrm{g} \\
\text { every } 8 \text { hours }\end{array}$ & NS & 31 & 8 \\
\hline $\begin{array}{l}\text { Tomassetti et al. } \\
\text { (1998) [45] }\end{array}$ & 18 & GI-NET & $\begin{array}{l}\text { Previous surgical resection } \\
\text { in } 28 \%\end{array}$ & $\begin{array}{l}\text { Lanreotide } 30 \mathrm{mg} \text { i.m. } \\
\text { every } 10 \text { days }\end{array}$ & $\begin{array}{l}5-18 \text { mos; } \\
\text { mean } 12 \text { mos }\end{array}$ & 0 & 78 \\
\hline $\begin{array}{l}\text { Wymenga et al. } \\
\text { (1999) [46] }\end{array}$ & 31 & $\begin{array}{l}\text { Progressive } \\
\text { GI-NET }\end{array}$ & $\begin{array}{l}\text { Previous surgical resection } \\
\text { in } 62 \% \text {; previous } \\
\text { immunotherapy in } 18 \% \text {; } \\
\text { previous chemotherapy in } \\
4 \%\end{array}$ & $\begin{array}{l}\text { Lanreotide ATG } 30 \mathrm{mg} \\
\text { every } 2 \text { wks, escalated to } \\
\text { weekly in } 27 \%\end{array}$ & $\begin{array}{l}6 \text { mos; mean } \\
21 \text { wks }\end{array}$ & 6 & 81 \\
\hline $\begin{array}{l}\text { Faiss et al. } \\
\text { (1999) [43] }\end{array}$ & 24 & $\begin{array}{l}\text { Progressive, } \\
\text { metastatic } \\
\text { GEP-NET }\end{array}$ & $\begin{array}{l}\text { Previous surgical resection } \\
\text { in } 53 \% \text {; previous interferon } \\
\text { in } 10 \% \text {; previous } \\
\text { chemotherapy in } 10 \%\end{array}$ & Lanreotide 5 mg s.c. t.i.d. & $1-12+\operatorname{mos}$ & 4 & 46 \\
\hline $\begin{array}{l}\text { Ducreux et al. } \\
(2000)[41]\end{array}$ & 39 & GI-NET & $\begin{array}{l}\text { ECOG PS } 0 \text { in } 35 \% \text {; ECOG } \\
\text { PS } 1 \text { in } 59 \% \text {, ECOG PS } 2 \text { in } \\
7 \% \\
\text { Previous surgical resection } \\
\text { in } 67 \% \text {; previous interferon } \\
\text { in } 15 \% \text {; previous } \\
\text { chemotherapy in } 43 \%\end{array}$ & $\begin{array}{l}\text { Lanreotide } 30 \mathrm{mg} \text { i.m. } \\
\text { every } 10-14 \text { days }\end{array}$ & $\begin{array}{l}12 \text { mos or until } \\
\text { tumor } \\
\text { progression }\end{array}$ & 5 & 49 \\
\hline $\begin{array}{l}\text { Ricci et al. } \\
(2000) \text { [44] }\end{array}$ & 25 & Metastatic NET & $\begin{array}{l}\text { All had ECOG PS }<2 \\
\text { Previous surgical resection } \\
\text { in } 100 \% \text {; previous } \\
\text { chemotherapy in } 16 \%\end{array}$ & $\begin{array}{l}\text { Lanreotide } 30 \mathrm{mg} \text { i.m. } \\
\text { every } 2 \text { wks }\end{array}$ & $\begin{array}{l}2-30+\operatorname{mos} \\
\text { median } 10 \text { mos }\end{array}$ & 8 & 40 \\
\hline $\begin{array}{l}\text { Aparicio et al. } \\
(2001)[24]\end{array}$ & 11 & Metastatic NET & $\begin{array}{l}\text { PS } 0 \text { in } 54 \% \text {; PS } 1 \text { in } 40 \% \text {; } \\
\text { PS }>1 \text { in } 6 \% \\
\text { Previous surgical resection } \\
\text { in } 77 \% \text {; previous } \\
\text { chemotherapy in } 74 \%\end{array}$ & $\begin{array}{l}\text { Lanreotide } 30 \text { mg i.m. } \\
\text { every } 2 \text { wks; could be } \\
\text { increased to every } 10 \\
\text { days }\end{array}$ & $\begin{array}{l}1-48 \text { mos; } \\
\text { median } 7 \operatorname{mos}^{\mathrm{a}}\end{array}$ & 0 & 55 \\
\hline $\begin{array}{l}\text { Faiss et al. } \\
(2003)[42]\end{array}$ & 25 & $\begin{array}{l}\text { Progressive } \\
\text { GEP-NET }\end{array}$ & $\begin{array}{l}\text { All had ECOG PS } \leq 2 \\
\text { Previous surgical resection } \\
\text { in } 51 \%\end{array}$ & Lanreotide 1 mg s.c. t.i.d. & $12 \mathrm{mos}$ & 4 & 28 \\
\hline $\begin{array}{l}\text { Bajetta et al. } \\
\text { (2006) [40] }\end{array}$ & 28 each & $\begin{array}{l}\text { Well-differentiated } \\
\text { NET }\end{array}$ & $\begin{array}{l}\text { All had ECOG PS } 0-2 \\
\text { Previous surgical resection } \\
\text { in } 95 \% \text {; previous interferon } \\
\text { in } 5 \% \text {; previous } \\
\text { chemotherapy in } 22 \%\end{array}$ & $\begin{array}{l}\text { Lanreotide LA } 60 \mathrm{mg} \\
\text { every } 3 \text { wks or lanreotide } \\
\text { ATG } 120 \mathrm{mg} \text { every } 6 \text { wks } \\
(1: 1)\end{array}$ & 18 wks & $\begin{array}{l}\text { Lanreotide } \\
\text { ATG: } 0 \\
\text { Lanreotide } \\
\text { LA: } 4\end{array}$ & $\begin{array}{l}\text { Lanreotide } \\
\text { ATG: } 68 \\
\text { Lanreotide } \\
\text { LA: } 64\end{array}$ \\
\hline $\begin{array}{l}\text { Panzuto et al. } \\
\text { (2006) [35] }\end{array}$ & 10 & $\begin{array}{l}\text { Well-differentiated, } \\
\text { progressive, } \\
\text { advanced pNET }\end{array}$ & $\begin{array}{l}\text { Previous surgical resection } \\
\text { in } 65 \% \text {; previous } \\
\text { chemotherapy in } 13 \%\end{array}$ & $\begin{array}{l}\text { Lanreotide SR } 60 \mathrm{mg} \\
\text { every } 28 \text { days }\end{array}$ & $\begin{array}{l}6-60 \text { mos; } \\
\text { median } 18 \\
\operatorname{mos}^{\mathrm{a}}\end{array}$ & 0 & 40 \\
\hline $\begin{array}{l}\text { Martin-Richard } \\
\text { et al. (2011) [47] }\end{array}$ & 30 & $\begin{array}{l}\text { Advanced and/or } \\
\text { metastatic, well- } \\
\text { differentiated NET }\end{array}$ & $\begin{array}{l}\text { ECOG PS } 0 \text { in } 63 \% \text {; ECOG } \\
\text { PS } 1 \text { in } 30 \% \text {; ECOG PS } 2 \\
\text { in } 7 \% \\
\text { Previous interferon in } 23 \% \text {; } \\
\text { previous chemotherapy in } \\
33 \%\end{array}$ & $\begin{array}{l}\text { Lanreotide ATG } 120 \mathrm{mg} \\
\text { every } 28 \text { days }\end{array}$ & $\begin{array}{l}\text { Until tumor } \\
\text { progression }\end{array}$ & 4 & 89 \\
\hline $\begin{array}{l}\text { CLARINET } \\
\text { study } \\
\text { (NCT00353496) }\end{array}$ & 265 & $\begin{array}{l}\text { Well-differentiated } \\
\text { or moderately } \\
\text { differentiated, } \\
\text { nonfunctioning } \\
\text { enteropancreatic } \\
\text { NET }\end{array}$ & TBD & $\begin{array}{l}\text { Lanreotide ATG } 120 \mathrm{mg} \\
\text { every } 28 \text { days }\end{array}$ & TBD & TBD & TBD \\
\hline
\end{tabular}

${ }^{a}$ Median duration of treatment includes all drug regimens.

Abbreviations: ATG, autogel; ECOG, Eastern Cooperative Oncology Group; GEP-NET, gastroenteropancreatic neuroendocrine tumor; GI-NET, gastrointestinal neuroendocrine tumor; LA, long acting; LAR, long-acting repeatable; NET, neuroendocrine tumor; NS, not specified; pNET, pancreatic neuroendocrine tumor; PS, performance status; SR, slowrelease; TBD, to be determined.

(SOM230), a novel somatostatin analog, may have potential antitumor properties. Pasireotide targets multiple somatostatin receptors, including subtype 3 , and has a higher affinity for subtypes 1 and 5 than octreotide and lanreotide [51]. Whether the ability to target additional somatostatin receptor subtypes translates to higher antitumor efficacy needs further investigation. Pasireotide has shown antiproliferative effects in vitro $[52,53]$. A randomized, double-blind, phase III trial of pasireotide LAR compared with octreotide LAR in patients with metastatic GI-NETs is ongoing (NCT00690430), and tumor 


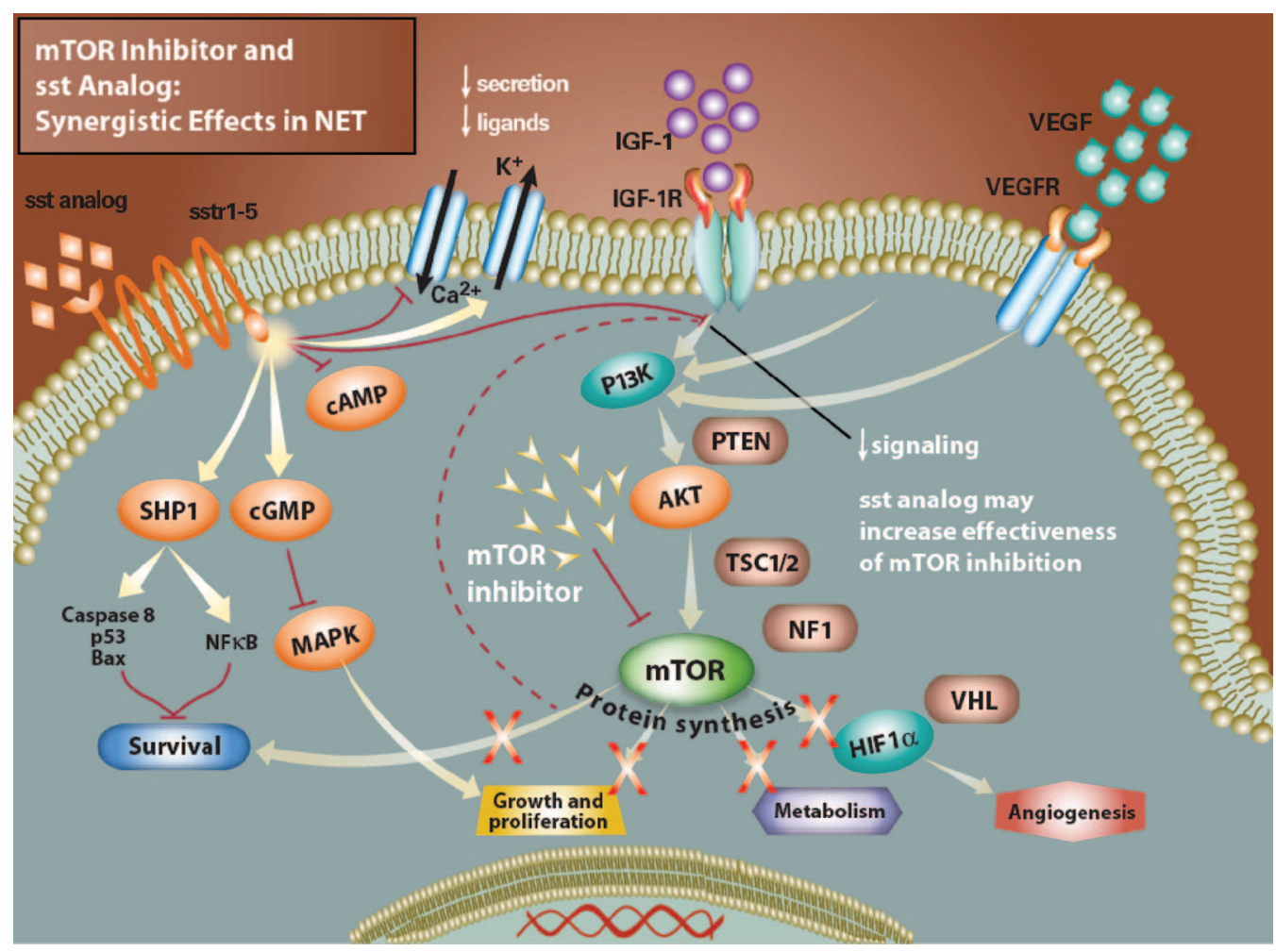

Figure 2. Effect of combined somatostatin analog and mammalian target of rapamycin (mTOR) inhibitor therapy in neuroendocrine tumors. Combined treatment with an mTOR inhibitor and a somatostatin analog has been shown to cause tumor cell cycle arrest in vitro [57]. The indirect inhibition of mTOR through phosphoinositase-3-kinase/Akt resulting from the somatostatin analog seems to increase sensitivity to mTOR inhibition.

Abbreviations: cAMP, cyclic adenosine monophosphate; cGMP, cyclic guanosine monophosphate; HIF, hypoxia-inducible factor; IGF, insulin-like growth factor; IGF-1R, insulin-like growth factor receptor 1, MAPK, mitogen-activated protein kinase; mTOR, mammalian target of rapamycin; NET, neuroendocrine tumor; NF1, nuclear factor 1; NF $\kappa \mathrm{B}$, nuclear factor- $\kappa \mathrm{B}$; PI3K, phosphoinositase-3-kinase; PTEN, phosphatase and tensin homolog; SHP1, Src homology phosphatase-1; sst, somatostatin; TSC, tuberous sclerosis complex; VEGF, vascular endothelial growth factor; VEGFR, vascular endothelial growth factor receptor; VHL, Von Hippel-Lindau.

response as measured by RECIST version 1.0 is a secondary endpoint of this trial.

Somatostatin analogs may also be used in combination with other treatments to enhance antiproliferative effects. The effect of octreotide in combination with the mammalian target of rapamycin (mTOR) inhibitor everolimus was examined for patients with GI-NET in the phase III, randomized, controlled RAD001 in Advanced Neuroendocrine Tumors (RADIANT-2) study [54]. Progression-free survival for octreotide plus placebo (11.3 months) is consistent with that reported in PROMID (14.3 months) [38]. Patients treated with everolimus plus octreotide LAR were more likely to experience tumor shrinkage than patients receiving placebo plus octreotide LAR (75\% vs. $45 \%)$, although the extent of shrinkage was not sufficient to be classified as an objective response as defined by RECIST [54].

In the RADIANT-1 phase II study of everolimus in patients with advanced pNETs, everolimus was added to octreotide LAR in a subset of patients $(n=45)$ with progressive pNETs who had been treated with octreotide LAR alone [55]. The median progression-free survival for these patients was 16.7 months (95\% CI: 11.1-not reached), and the objective response rate was $4.4 \%$ [55]. Thus, there is a rationale for the everolimus plus octreotide LAR therapeutic combination because antitumor effects may be enhanced by simultaneously targeting upstream and downstream components of the mTOR pathway (Fig. 2) [56, 57]. Other treatment options being assessed in combination with somatostatin analogs include agents targeted against vascular endothelial growth factor (NCT00569127, NCT00427349), epidermal growth factor receptor (NCT01121939), insulin-like growth factor-1 receptor (NCT01204476), and techniques such as radioembolization with resin microspheres (NCT00466856). The results of these studies are awaited with interest.

\section{Conclusions}

The randomized phase III PROMID trial is the only placebocontrolled clinical trial to date that demonstrates the antitumor effects of somatostatin analogs, specifically octreotide. Published results of uncontrolled clinical trials of the antitumor effect of octreotide in patients with NETs are consistent with these results. In addition to symptom control for patients with 
NETs, the data support an antitumor effect of octreotide and suggest that it may slow tumor growth. Data for lanreotide in phase II trials show similar results, although results of the placebo-controlled, phase III trial of patients with intestinal NETs and pNETs (CLARINET) are not expected until 2013. Further controlled trials in a larger number of patients are needed to identify prognostic factors to antitumor response and to confirm whether the antitumor effect of octreotide translates to a survival benefit.

\section{ACKNOWLEDGMENTS}

We thank Sara Duggan, Ph.D., and Jennifer M. Kulak, Ph.D., of ApotheCom for editing assistance in the preparation of this manuscript. Editorial compensation was provided by Novartis Oncology.

\section{Author Contributions}

Conception/Design: Lucas Sidéris, Pierre Dubé, Anja Rinke

Manuscript writing: Lucas Sidéris, Pierre Dubé, Anja Rinke

Final approval of manuscript: Lucas Sidéris, Pierre Dubé, Anja Rinke

\section{REFERENCES}

1. Kulke MH, Siu LL, Tepper JE et al. Future directions in the treatment of neuroendocrine tumors: Consensus Report of the National Cancer Institute Neuroendocrine Tumor Clinical Trials Planning Meeting. J Clin Oncol 2011;29:934-943.

2. Vinik AI, Woltering EA, Warner RR et al. NANETS consensus guidelines for the diagnosis of neuroendocrine tumor. Pancreas 2010;39:713-734.

3. Yao JC, Hassan M, Phan A et al. One hundred years after "carcinoid": Epidemiology of and prognostic factors for neuroendocrine tumors in 35,825 cases in the United States. J Clin Oncol 2008;26:3063-3072.

4. Plockinger U, Rindi G, Arnold R et al. Guidelines for the diagnosis and treatment of neuroendocrine gastrointestinal tumours: A consensus statement on behalf of the European Neuroendocrine Tumour Society (ENETS). Neuroendocrinology 2004;80:394-424.

5. Kulke MH, Anthony LB, Bushnell DL et al. NANETS treatment guidelines: Well-differentiated neuroendocrine tumors of the stomach and pancreas. Pancreas 2010;39:735-752.

6. Appetecchia M, Baldelli R. Somatostatin analogues in the treatment of gastroenteropancreatic neuroendocrine tumours, current aspects and new perspectives. J Exp Clin Cancer Res 2010;29:19.

7. Somatuline Autogel: Summary of product characteristics. Uppsala, Sweden: Pharmacia; 2002.

8. Sandostatin LAR depot (octreotide acetate for injectable suspension). East Hanover, NJ: Novartis Pharmaceutical Corporation; 2010.

9. Lightman S. Somatuline autogel: An extended release lanreotide formulation. Hosp Med 2002;63:162165.

10. Oberg K, Kvols L, Caplin M et al. Consensus report on the use of somatostatin analogs for the management of neuroendocrine tumors of the gastroenteropancreatic system. Ann Oncol 2004;15:966-973.

11. Somatuline LA: Summary of product characteristics. Brisbane, CA: Ipsen; 2002.

12. De Herder WW, Hofland LJ, Van Der Lely AJ, Lamberts SW. Somatostatin receptors in gastroenteropancreatic neuroendocrine tumours. Endocr Relat Cancer 2003; 10:451-458.

13. Villaume K, Blanc M, Gouysse $\mathrm{G}$ et al. VEGF secretion by neuroendocrine tumor cells is inhibited by octreotide and by inhibitors of the PI3K/AKT/mTOR pathway. Neuroendocrinology 2010;91:268-278.

14. Sandostatin LAR: Summary of product characteristics. Uppsala, Sweden: Pharmacia; 2002.

15. Kvols LK, Moertel CG, O'Connell MJ et al. Treatment of the malignant carcinoid syndrome: Evaluation of a long-acting somatostatin analogue. N Engl J Med 1986;315:663-666.

16. Rubin J, Ajani J, Schirmer W et al. Octreotide acetate long-acting formulation versus open-label subcuta- neous octreotide acetate in malignant carcinoid syndrome. J Clin Oncol 1999;17:600-606.

17. Smith CS, Houston M, Jensen B et al. A 32-yearold man with copious, watery diarrhea. N C Med J 2001; 62:134-139.

18. Clements D, Elias E. Regression of metastatic vipoma with somatostatin analogue SMS 201-995. Lancet 1985; $1: 874-875$

19. Shepherd JJ, Senator GB. Regression of liver metastases in patient with gastrin-secreting tumour treated with SMS 201-995. Lancet 1986;2:574

20. Susini C, Buscail L. Rationale for the use of somatostatin analogs as antitumor agents. Ann Oncol 2006; 17:1733-1742.

21. Strosberg J, Kvols L. Antiproliferative effect of somatostatin analogs in gastroenteropancreatic neuroendocrine tumors. World J Gastroenterol 2010;16:29632970.

22. Angeletti S, Corleto VD, Schillaci O et al. Single dose of octreotide stabilize metastatic gastro-enteropancreatic endocrine tumours. Italian J Gastroenterol Hepatol 1999;31:23-27.

23. Anthony L, Johnson D, Hande K et al. Somatostatin analogue phase I trials in neuroendocrine neoplasms. Acta Oncol 1993;32:217-223.

24. Aparicio T, Ducreux M, Baudin E et al. Antitumour activity of somatostatin analogues in progressive metastatic neuroendocrine tumours. Eur J Cancer 2001;37: 1014-1019.

25. Arnold R, Rinke A, Klose KJ et al. Octreotide versus octreotide plus interferon-alpha in endocrine gastroenteropancreatic tumors: A randomized trial. Clin Gastroenterol Hepatol 2005;3:761-771.

26. Arnold R, Trautmann ME, Creutzfeldt $\mathrm{W}$ et al. Somatostatin analogue octreotide and inhibition of tumour growth in metastatic endocrine gastroenteropancreatic tumours. Gut 1996;38:430-438.

27. Bajetta E, Catena L, Procopio G et al. Is the new WHO classification of neuroendocrine tumours useful for selecting an appropriate treatment? Ann Oncol 2005; 16:1374-1380

28. di Bartolomeo M, Bajetta E, Buzzoni R et al. Clinical efficacy of octreotide in the treatment of metastatic neuroendocrine tumors: A study by the Italian Trials in Medical Oncology Group. Cancer 1996;77:402-408.

29. Oberg K, Norheim I, Theodorsson E. Treatment of malignant midgut carcinoid tumours with a long-acting somatostatin analogue octreotide. Acta Oncol 1991;30: 503-507.

30. Ricci S, Antonuzzo A, Galli L et al. Octreotide acetate long-acting release in patients with metastatic neuroendocrine tumors pretreated with lanreotide. Ann Oncol 2000;11:1127-1130.

31. Saltz L, Trochanowski B, Buckley M et al. Octreotide as an antineoplastic agent in the treatment of functional and nonfunctional neuroendocrine tumors. Cancer 1993;72:244-248.
32. Tomassetti P, Migliori M, Corinaldesi R, Gullo L. Treatment of gastroenteropancreatic neuroendocrine tumours with octreotide LAR. Aliment Pharmacol Ther 2000; 14:557-560

33. Vinik A, Moattari AR. Use of somatostatin analog in management of carcinoid syndrome. Dig Dis Sci 1989;34:14S-27S.

34. Butturini G, Bettini R, Missiaglia E et al. Predictive factors of efficacy of the somatostatin analogue octreotide as first line therapy for advanced pancreatic endocrine carcinoma. Endocr Relat Cancer 2006;13: 1213-1221.

35. Panzuto F, Di Fonzo M, Iannicelli E et al. Longterm clinical outcome of somatostatin analogues for treatment of progressive, metastatic, well-differentiated entero-pancreatic endocrine carcinoma. Ann Oncol 2006; 17:461-466.

36. Shojamanesh H, Gibril F, Louie A et al. Prospective study of the antitumor efficacy of long-term octreotide treatment in patients with progressive metastatic gastrinoma. Cancer 2001;94:331-343.

37. Pavel ME, Heuck F, Plockinger U et al. Prospective randomized trial: Biotherapy versus chemotherapy in malignant nonfunctional neuroendocrine tumors of the pancreas and bronchial tract (ENET-1). Paper presented at the Gastrointestinal Cancers Symposium; January 2527, 2008; Orlando, FL.

38. Rinke A, Muller HH, Schade-Brittinger $\mathrm{C}$ et al. Placebo-controlled, double-blind, prospective, randomized study on the effect of octreotide LAR in the control of tumor growth in patients with metastatic neuroendocrine midgut tumors: A report from the PROMID Study Group. J Clin Oncol 2009;27:46564663.

39. Chadha MK, Lombardo J, Mashtare T et al. Highdose octreotide acetate for management of gastroenteropancreatic neuroendocrine tumors. Anticancer Res 2009;29:4127-4130.

40. Bajetta E, Procopio G, Catena L et al. Lanreotide autogel every 6 weeks compared with lanreotide microparticles every 3 weeks in patients with well differentiated neuroendocrine tumors: A phase III study. Cancer 2006; 107:2474-2481.

41. Ducreux M, Ruszniewski P, Chayvialle JA et al. The antitumoral effect of the long-acting somatostatin analog lanreotide in neuroendocrine tumors. Am J Gastroenterol 2000;95:3276-3281.

42. Faiss S, Pape UF, Bohmig M et al. Prospective, randomized, multicenter trial on the antiproliferative effect of lanreotide, interferon alfa, and their combination for therapy of metastatic neuroendocrine gastroenteropancreatic tumors: The International Lanreotide and Interferon Alfa Study Group. J Clin Oncol 2003;21:26892696.

43. Faiss S, Rath U, Mansmann U et al. Ultra-highdose lanreotide treatment in patients with metastatic neuroendocrine gastroenteropancreatic tumors. Digestion 1999;60:469-476. 
44. Ricci S, Antonuzzo A, Galli L et al. Long-acting depot lanreotide in the treatment of patients with advanced neuroendocrine tumors. Am J Clin Oncol 2000; 23:412-415.

45. Tomassetti P, Migliori M, Gullo L. Slow-release lanreotide treatment in endocrine gastrointestinal tumors. Am J Gastroenterol 1998;93:1468-1471.

46. Wymenga AN, Eriksson B, Salmela PI et al. Efficacy and safety of prolonged-release lanreotide in patients with gastrointestinal neuroendocrine tumors and hormone-related symptoms. J Clin Oncol 1999;17:1111.

47. Martin-Richard M, Alonzo V, Marmol $\mathrm{M}$ et al. Evaluation of the efficacy and the safety of lanreotide autogel $120 \mathrm{mg}$ on tumor growth stabilization in patients with progressive neuroendocrine tumors (NET) who are not eligible to surgery or chemotherapy. J Clin Oncol 2011;29:e14660.

48. Anthony LB, Strosberg JR, Klimstra DS et al. The NANETS consensus guidelines for the diagnosis and management of gastrointestinal neuroendocrine tumors (NETS): Well-differentiated nets of the distal colon and rectum. Pancreas 2010;39:767-774.
49. Boudreaux JP, Klimstra DS, Hassan MM et al. The NANETS consensus guideline for the diagnosis and management of neuroendocrine tumors: Well-differentiated neuroendocrine tumors of the jejunum, ileum, appendix, and cecum. Pancreas 2010;39:753-766.

50. Oberg K, Akerstrom G, Rindi G, Jelic S. Neuroendocrine gastroenteropancreatic tumours: ESMO Clinical Practice Guidelines for diagnosis, treatment and followup. Ann Oncol 2010;21 suppl 5:v223-v227.

51. Bruns C, Lewis I, Briner U et al. SOM 230 : A novel somatostatin peptidomimetic with broad somatotropin release inhibiting factor (SRIF) receptor binding and a unique antisecretory profile. Eur J Endocrinol 2002;146: 707-716.

52. Pavel M, Hassler G, Schmid HA et al. Pasireotide strongly inhibits migration and proliferation of human micro- and macrovascular endothelial cells mainly via somatostatin receptor subtype 5 and FAK, ERK1/2 and p38 pathways. Endocrinology 2006;147:352.

53. Pasquali D, Rossi V, Conzo G et al. Effects of somatostatin analog SOM230 on cell proliferation, apop- tosis, and catecholamine levels in cultured pheochromocytoma cells. J Mol Endocrinol 2008;40:263-271.

54. Pavel ME, Hainsworth JD, Baudin E et al. Everolimus plus octreotide long-acting repeatable for the treatment of advanced neuroendocrine tumours associated with carcinoid syndrome (RADIANT 2): A randomised, placebo-controlled, phase 3 study. Lancet 2011;378: 2005-2012.

55. Yao JC, Lombard-Bohas C, Baudin E et al. Daily oral everolimus activity in patients with metastatic pancreatic neuroendocrine tumors after failure of cytotoxic chemotherapy: A phase II trial. J Clin Oncol 2010;28: 69-76.

56. Strosberg JR, Kvols LK. A review of the current clinical trials for gastroenteropancreatic neuroendocrine tumours. Expert Opin Invest Drugs 2007;16: 219-224.

57. Cerovac V, Monteserin-Garcia J, Rubinfeld HB et al. The somatostatin analogue octreotide confers sensitivity to rapamycin treatment on pituitary tumor cells. Cancer Res 2010;70:666-674.

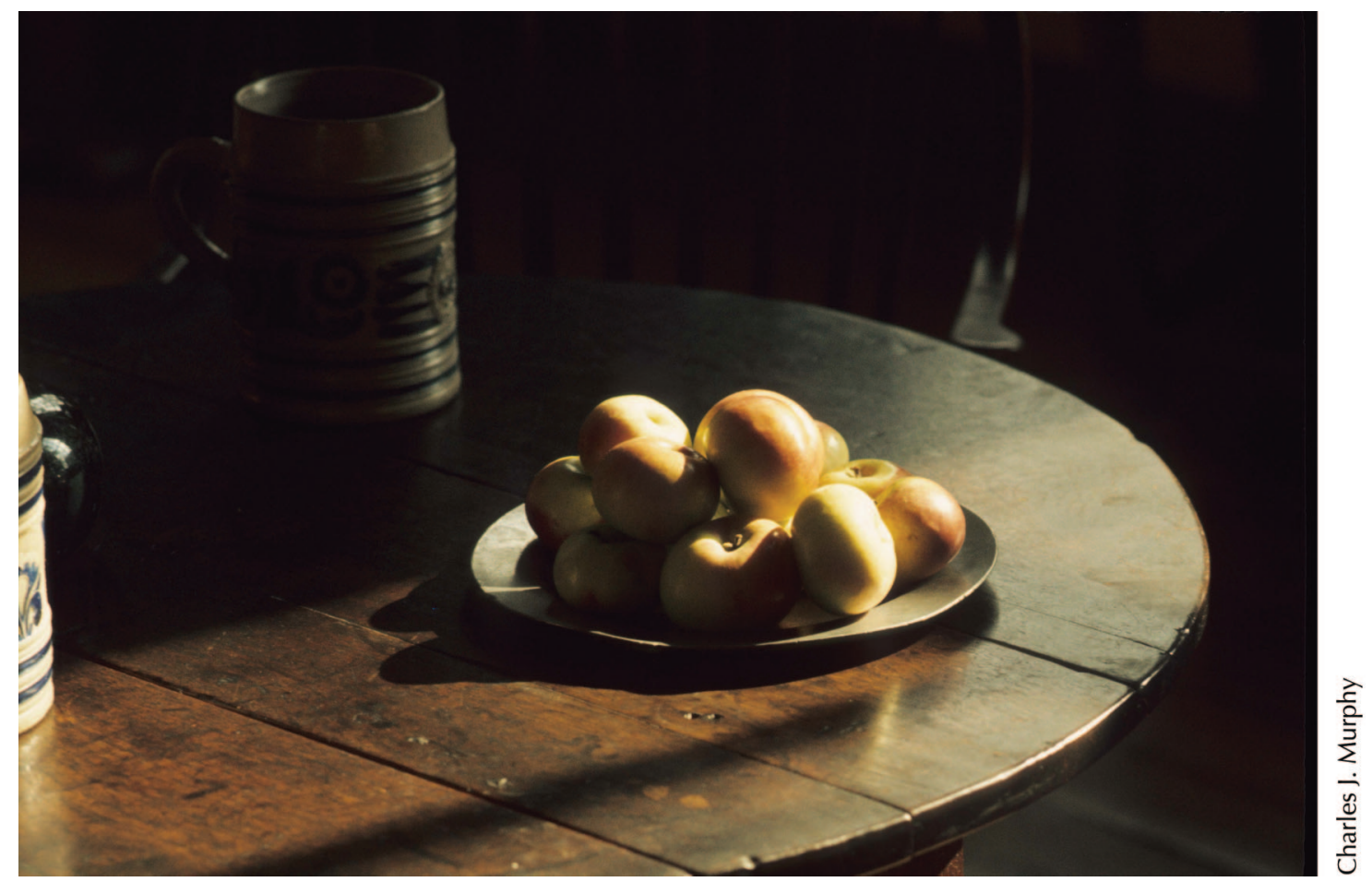

